and state of differentiation for these may affect the expression of reverse transcriptase in non-malignant cells. At present it is not obvious why Spiegelman and his colleagues have repeatedly failed to detect the activity in normal white blood cells, but the observation that the activity detected in crude extracts depends on the protein concentrations in the assays may have something to do with it. Furthermore, it now seems clear that antimetabolites specific for reverse transcriptases will not be specific for malignant cells-a great disappointment.

Aside from the cancer problem, the discovery of reverse transcriptases in some non-malignant, apparently normal cells has many implications for molecular and cell biology. Assuming that the normal cells Scolnick et al. used were not accidentally infected with a tumour or foamy virus during their period in culture, which seems extremely unlikely, the reverse transcriptase which they contain must have been specified by a genetic element in the cells, either a latent and vertically transmitted virus or some cellular gene. In these days of oncogenes (putative cellulär genes capable of causing a cell to go malignant and of becoming part of a tumour virus) and protoviruses (putative cellular messenger RNAs which together with reverse transcriptase may escape a cell and, being infectious, transfer their genetic information to another cell), the distinctions between the genome of a cell and of some of the viruses which infect that cell are fast vanishing, in theory at least. Both the oncogenic and protovirus hypotheses postulate that tumour viruses are escaped cellular genetic elements, and such a ferment of revolutionary ideas cries out for rigorous experimental testing. In particular we need to know in detail the comparative biochemistry of reverse transcriptases purified from various sources.

\title{
Ring out the Old, Ring in the New
}

IT comes as quite a shock to realize that, only ten years ago, the paper by Drs Dietz and Holden which appears on page 309 of this issue of Nature would have been regarded as a joke. Speculation on the existence of preMesozoic ocean floor would, at that time, have been a bit like asking whether there is any sand in the desert, and would have been dismissed with the sort of contempt normally reserved for those ancient philosophers who wrangled at length on the question of angels on pin points. For such is the revolution that has taken place in the Earth sciences over the past decade that the oceans, once the oldest and most mysterious part of the Earth, now appear as young features with comparatively simple geology and with histories far less complex than that represented by the contortions of the continents more than 3,500 million years ago.

It is easy to see, in retrospect, that the reason why the oceans were what they were to the old geologists was largely a matter of ignorance. Of course, in the broad sense the reason for any wrong idea is ignorance; but in the case of the oceans, the point has a particular relevance. For the oceans were at least as old as the continents not because this was a postulate or necessary consequence of some all-embracing global theory of Earth behaviour, but only because there was no reason to suppose otherwise. In short, the ocean floors were thousands of millions of years old by default--there was simply no reason to think that the sort of tectonic process which has been a feature of continental history should not also be typical of the oceanic crust. If there was an alternative view at all, it was only that tectonic activity in the ocean floor might have been less frequent than on the continents. Few thought of the possibility that the oceans might be susceptible to vastly different forms of tectonic activity.

Thus it was that the lack of any large scale horizontal movement in the continental crust was, perhaps understandably, carried over to the ocean floors with little refinement. If detailed bathymetric surveys of the ocean floor had been available, the obsession with vertical movement may not have lasted quite so long. As it was, in ignorance of the true situation the oceans became the receptacle for all sorts of problems which could not be solved in any other way. For instance, to explain the distribution of similar flora and fauna between continents separated by vast stretches of sea, it was necessary to invoke the unlikely concept of land bridges-narrow strips of dry land which once spanned oceans but which, having served their avowed purpose, sank out of sight. As long as there was no way of detecting sunken land bridges, this theory of vertical land movement served its purpose well enough. But once the veil of factual ignorance had been removed, the vertical limitation was revealed for the ad hoc assumption it was.

And so the picture of the oceans began to change. Long before the so-called revolution of the 1960s, the young science of seismology had begun to reveal the oceans as sites of peculiar activity; and it soon became apparent that, devastating though earthquakes in inhabited continental areas might be, the oceans were far more prone to seismic activity. Then, in the later 1950s, the first comprehensive bathymetric charts of the ocean floors showed that, far from there being sunken land bridges, the most impressive topographic features were the mid-oceanic ridges which combine to form practically a continuous system tens of thousands of miles long. From this it was but a short step to correlating midoceanic ridges with the sites of the majority of the world's earthquake epicentres.

But satisfying though the new vision of the oceans may be from the purely academic point of view, the new global tectonics has its practical disappointments. Today, the oceans are often regarded as the great blue hope for solving the world food problem; but it is easy to forget that not so very long ago the ocean floor was also regarded as a vast potential mineral El Dorado.

Whether, as Dietz and Holden imply, possible preMesozoic ocean floor offers the prospect of useful minerals whose retrieval is economically viable remains to be seen. And whether, as they suggest, the Wharton Basin in the Indian Ocean is just such pre-Mesozoic crust remains to be tested directly. What is certain is that historians of the future will have much more fun charting the events which transformed the pre-Mesozoic from the old young to the new old. 